pp. $682-690$

\title{
Control and Supervisory Proceedings in the Mechanism of Protecting the Rights and Legitimate Interests of Business Entities
}

\author{
Submitted 06/06/20, 1st revision 26/07/20, 2nd revision 25/08/20, accepted 15/09/20 \\ O.V. Shmaliy ${ }^{1}$, G.O. Vladimirovna ${ }^{2}$, D.L. Anatolievna ${ }^{3}$, \\ M.A. Magomedbasirovna ${ }^{4}$, S.M. Magomedbasirovich ${ }^{5}$, A.I. Vladimirovna ${ }^{6}$
}

\begin{abstract}
:
Purpose: The purpose of this study is to determine the importance of control and supervisory proceedings in the mechanism of protecting the rights and legitimate interests of business entities.

Design/Methodology/Approach: To achieve this goal the following general and private scientific methods have been used. The dialectical, logical, systematic, comprenhensive and comparative-legal analyses.

Findings: The article examines questions for formation control and supervisory proceedings as a mechanism to protect the rights and lawful interests of business entities. The necessity of separating the control and supervisory proceedings as an independent type of administrative administrative and procedural activity of executive authorities is substantiated, which will allow to properly ensure the rights and legitimate interests of economic entities. As a result of the study, it is concluded that there is an active process of forming the proceduralization of control and supervisory activities, which is due to the need for a uniform approach of control and supervisory authorities when applying administrative and legal response measures to the study of circumstances indicating the presence of violations of mandatory requirements or requirements established legal acts.

Practical Implications: Improving the legal mechanisms of control and supervision of production will allow to achieve the improvements I have the relationship of government and business, reducing excess pressure on legal entities of different legal forms of ownership and individual entrepreneurs.
\end{abstract}

${ }^{I}$ The Head A of the Administrative and Information law Department of Russian Academy of National, Economy and State Administration of the Russian Federation, Moscow, Russian Federation, shok93@yandex.ru;

${ }^{2}$ Professor of the Administrative and Information law Department of Russian Academy of National Economy and State Administration of the Russian Federation, Moscow, Russian Federation

${ }^{3}$ The Head of the Administrative and Service Law of the South Russian Institute of Management of Russian Academy of National Economy and State Administration under the President of the Russian Federation, Rostov-on-Don, Russian Federation

${ }^{4}$ Lecture of the College of Dagestan State University, Makhachkala, Russian Federation

${ }^{5}$ Lecture of Rostov Institute (branch) of All - Russian State University of Justice of

Russian Legal Academy of Ministry of Justice of Russia, Rostov-on-Don, Russian Federation ${ }^{6}$ Lawyer of the Rostov Region bar Association "Kuyumdzhi, Valeeva and partners", Rostovon-Don, Russian Federation 
Originality /Value: The findings made by the results of this study, will contribute to improving the effectiveness of the protection of rights and legal interests of business entities during the supervisory activities subjects of public administration.

Keywords: Control, supervision, mandatory requirements, control and supervision activities.

JEL Classification Codes: K2, O29.

Paper type: Research article.

Acknowledgment: The study was carried out as part of the research work of the state assignment by the Russian Academy of National Economy and Public Administration under the President of the Russian Federation No. 12.25 on the topic: "Modern approaches to the formation of legal support for reforming control and supervisory activities."

\section{Introduction}

The aggravation of political processes against the background of the high mobility of the current legislation in connection with the constitutional reform requires the development of qualified forms of control over the implementation of administrative processes in the public authority system. It is obvious that the efforts of legislative initiatives to improve control and supervision in public administration are aimed at improving the relationship between government and business, are considered as a tool to reduce excessive pressure on legal entities of various legal forms of ownership and individual entrepreneurs.

However, not always consistent and deliberate modernization of control and oversight activities is explained not only by weak theoretical elaboration, but also by an obviously insufficient analysis of the law enforcement practice of control and oversight bodies, which is classically reflected in the imperfection of the current legislation governing control and supervision in public administration. The authors of this study put forward a hypothesis according to which a procedural model of control and supervision proceedings has not yet been formed in domestic legislation. At the same time, the preconditions for its legislative regulation have been formed long ago.

The aim of the study is to test this hypothesis, to determine the significance of control and supervisory proceedings in the mechanism of protecting the rights and legitimate interests of business entities , which involves solving the following tasks: determining the essence and content of control and supervisory proceedings ; analysis of trends in the formation of a procedural model of control and supervision production .

The object of the research is public relations in the field of public regulation of economic activity. The subject of the research is legal norms, including design ones that form a procedural model of control and supervisory proceedings, and an accompanying legal doctrine. 


\section{Theoretical Foundation and Methodology}

Theoretical basis of research was made scientific works in the field of legal regulation of state control and supervision, among which are the studies of Martynov (2009), Zyryanov (2010), Nozdrachev (2017),) and others. The research is also based on works in the field of procedural and legal regulation of control and supervisory activities, in particular by such authors as Khabrieva and Marcoux (2011), Stakhov (2015) and others.

The analysis of the degree of elaboration of the studied problematics showed that today in the legal doctrine, firstly, active discussions are continuing on the issue of the correlation of control and supervision as ways of ensuring the rule of law in public administration, and secondly, active research is being conducted on the institute of control and supervision production and administrative - procedural regime of the model of control and supervisory production. Control and supervisory legislation is going through a period of fundamental transformation and a change in ideology, therefore, it must have high-quality doctrinal support. In this regard, we believe that it is necessary to conduct a comprehensive study, due to the above goals and objectives, as well as the subject area.

Empirical basis of research was made normative legal acts of the current national legislation, including acts of goal setting, federal laws, and acts of Presidio e coagulant of the Russian Federation and the Russian Federation. The methodological basis of the research was mainly made up of general scientific methods, including analysis, synthesis, induction, deduction. A special formal legal research method was also used.

\section{Results and Discussion}

Competent and consistent streamlining of procedural mechanisms of control and supervisory proceedings is of great importance for achieving a reference relationship between the authorities and business, providing for the reduction of excessive pressure on legal entities. On the one hand, this introduces legal criteria for the competence of state control (supervision) bodies, on the other hand, it limits the possibility of abuse by their officials and consolidates the basic guarantees for the protection of the rights and legitimate interests of controlled persons. The current legislative situation does not allow us to speak of an adjusted procedural model of control and supervisory proceedings.

The main characteristics that make it possible to consider the content of control and supervisory proceedings are the goals, functions, tasks, principles, and forms of such activities. The target orientation of the control and supervisory proceedings is manifested in the consistently performed actions of executive authorities and their officials, regulated by administrative procedures, and focused on preventing, identifying and suppressing violations of the requirements established by law. As the 
grounds for the application of preventive administrative procedures for control and supervision proceedings, the current legislation defines: the emergence of sources of threats to security or harm (life, health of citizens, the environment, etc.); signs of violation of legislation (antimonopoly, in the field of consumer rights, in the field of industrial safety, etc.); expiration of the established deadlines (frequency of inspections in relation to hazardous production facilities , after an inspection of a legal entity, from the beginning of entrepreneurial activity, etc.); occurrence or threat of emergencies of natural and man-made character.

The entire cycle of control and supervision production is based on several principles. Control and supervisory proceedings, the implementation of which in the activities of authorized state bodies pursues specific preventive, protective and suppressive goals, is in the legal mechanism of application and compliance with all principles of state control and supervision. A significant amount of legislation in the field of state control and supervision emphasizes the complexity and multidimensionality of the typification of the principles of control and supervision proceedings. The principles of control and supervisory proceedings form a complex and coordinated chain of procedural foundations, where the content of each principle, their correlation, determine the functioning of the entire system of control and supervisory activities.

In control and supervisory activities, an approach to the presentation of requirements to the controlled entity when carrying out verification activities in terms of their necessity and proportionality, inadmissibility of interference in its operational activities is of great importance. In this regard, the Constitutional Court of the Russian Federation, in its Resolution of February 17, 2015 No. 2-P, explained that the legal regulation of control and supervisory procedures "must meet the constitutional criteria for possible restrictions on human and civil rights and freedoms, which are enshrined in Part 3 of Art. 55 of the Constitution of the Russian Federation".

The current legal regulation ( Federal Law of December 26, 2008 No. 294-FZ " On the Protection of the Rights of Legal Entities and Individual Entrepreneurs in the Exercise of State Control (Supervision) and Municipal Control" ) defines a set of control measures that aggregates the heterogeneous powers of state bodies in the exercise of control and supervisory activities. Control measures include inspections, control and supervisory activities and control and supervisory actions. Such a combination of control and supervisory powers does not create clarity for the law enforcement officer, testifies to the absence of a clearly expressed paradigm of constructive interaction between state control and supervisory authorities and controlled economic entities. Legal uncertainty in the algorithms of control and supervision production negatively affects the level of security of controlled persons.

The legal and technical lack of development of such an important sphere of public relations can discredit the state power and form a conviction in the vulnerability of guarantees of the rights and legitimate interests of economic entities and their quality 
support from the state. The legal standard for the content of procedures for control and supervisory proceedings, including the application of measures of administrative and legal response, presupposes the existence of a procedural justification for the successive actions of state control (supervision) bodies in procedural forms determined by law.

Control and supervisory activity is recognized as preventive activity in the format of minimizing harm (damage) to legally protected values and stimulating the conscientious behavior of controlled persons, preceding the jurisdictional activity of authorized bodies on the application of punishments for committed administrative offenses. Identifying the violation of mandatory requirements or requirements established by legal acts, assumes the response in the form of prescriptions about their elimination and prevention of possible damage. The legal consequence for the business entity for the failure to execute the specified prescriptions is the legal responsibility. The application of measures of administrative and legal response during control and supervisory activities indicates the occurrence of an event of an administrative offense. However, not every violation of mandatory or other requirements is recognized as an administrative offense by virtue of the current legislation.

Nevertheless, if the detected violation simultaneously forms an event of an administrative offense, then the control and supervisory authority initiates an administrative offense case. At the same time, the issue of the moment of initiation of an administrative offense case remains open. The legislative attribution of the moment of initiation of an administrative offense case is tied to the act on the inspection, with the exception of the case provided for by the footnote to Article 28.1 of the Administrative Offenses Code of the Russian Federation, and does not contain an indication of such an act of control and supervisory response as an order ( Code of the Russian Federation on Administrative Offenses of 30 December 2001 No. 195FZ ).

If the control and supervisory body detects a violation of mandatory requirements or other requirements containing signs of an administrative offense, a protocol on the administrative offense is drawn up immediately. At the same time, for certain types of offenses initiated based on the results of an audit (in the field of state defense orders, antimonopoly regulation, etc.), the legislator allows an exception, determining that the reason for initiating these cases of administrative offenses is the entry into force of the decision of the commission of control and supervisory authority.

It seems reasonable that with regard to violations of mandatory requirements that simultaneously contain signs of an administrative offense, which did not entail real harm, did not create a threat of causing harm and can be promptly eliminated, the state control (supervision) body may limit itself to the use of control and supervisory procedures in relation to the audited entity. 
In law enforcement practice, it is not uncommon for officials of control and supervisory bodies to simultaneously issue an order to verified persons and initiate a case on an administrative offense, and upon consideration of such a case, administrative punishments are imposed. In this regard, it seems advisable to provide for the possibility of releasing a person who has committed an administrative offense from administrative liability in the event that an order is issued to him to eliminate the identified violation (Stakhov, 2015).

A mechanism for resolving a dispute arising from the results of a control and supervisory audit is legally established, which provides, among other things, the possibility of a prejudicial procedure for overcoming disagreements. In case of disagreement with the conclusions set out in the inspection report, or with an order issued to eliminate the identified violations, the inspected person has the right to submit objections to the state control (supervision) body. The pre-trial (extrajudicial) procedure for resolving a dispute is seen as the preferred stage (form) of advancing the control and supervisory case in order to ensure the promptness of the consideration of the case and making a decision on it, it does not require additional costs and can be effective both in terms of the time of consideration and in terms of financial security. In turn, failure to file an objection does not deprive the person being inspected of the right to appeal the results of the inspection in court.

The law also provides for the right of the inspected persons to appeal against the actions (inaction) of officials of the state control (supervision) body, which entailed a violation of the rights of a legal entity during the inspection, in administrative and (or) judicial procedure. However, an analysis of the law enforcement practice of control and supervisory bodies shows that citizens, legal entities, decisions, and actions (inaction) of officials of control and supervisory bodies in the administrative and (or) judicial procedure practically do not appeal. This kind of situation can be explained by a number of reasons: poor awareness of the possibility of protection, lack of confidence in the possibility of obtaining protection from the state control (supervision) bodies, controlled persons generally adequately relate to administrative and legal response measures, but at the same time to administrative and punitive measures. are critical, believing that this violates their rights and is an instrument of restricting freedom of entrepreneurship and property rights, and they express their disagreement, exercising the right to go to court for the protection of their violated or disputed rights and legitimate interests.

Judicial control in the order of administrative proceedings over the legality and reasonableness of the exercise of powers by state control (supervision) bodies, including over the observance of the rights of controlled persons in the implementation of certain administrative power requirements to controlled persons, is carried out by courts of general jurisdiction and arbitration courts.

For the purpose of the validity and legality of the exercised powers, the state control (supervision) bodies in the framework of the control and supervisory proceedings 
collect evidence of a violation of mandatory requirements, which in some cases indicate a high probability of such a violation and may be the basis for issuing an order, and in some cases may be evidence in the case of an administrative offense. In the latter case, the legislator may be advised to develop procedural rules for the use of the results of the audit carried out in proceedings on administrative offenses, as well as when considering these cases, complaints against decisions, actions (inaction) of the control and supervisory authorities, along with other evidence in accordance with the arbitration the procedural legislation of the Russian Federation, the legislation of the Russian Federation on administrative offenses or the legislation on administrative proceedings.

The measures of administrative and legal response applied by the state control (supervision) bodies within the framework of control and supervisory proceedings necessitate an adequate use of the institution of evidence and proof during the consideration of cases of administrative offenses, complaints against decisions, actions (inaction) of control and supervisory bodies, with in order to exclude the future infliction of legal consequences on the inspected person, aggravating his legal status.

It is possible to state some external similarity between the measures of administrative and legal response used by state control (supervision) bodies in the framework of control and supervision proceedings, and measures of administrative and procedural support. At the same time, administrative and legal response measures are the reaction of the control and supervisory body to violation of mandatory requirements or requirements established by legal acts, and are characterized by direct interference in the activities of the inspected person, while administrative and procedural support measures are applied in order to create the necessary conditions for timely and correct consideration of the case on an administrative offense.

The issues of the ratio and sufficiency of control and supervisory measures and similar measures of administrative and procedural support should be within the boundaries of compliance with the principle of proportionality of the measures applied to the content of committed violations of mandatory requirements or requirements established by legal acts. Therefore, the legislative regulation of the characteristic features and features of the application of administrative and legal response measures applied by state control (supervision) bodies will make it possible to form a legal mechanism for their use within the framework of proceedings for bringing to administrative responsibility, or application within the framework of control and supervisory proceedings, which allows sufficient eliminate violations of mandatory requirements or requirements established by legal acts by issuing and executing the order of the authority. It is also important to establish clear justified criteria for identifying the types of violations of mandatory requirements, which simultaneously form the events of the corresponding administrative offenses, upon detection of which the control and supervisory body may limit itself to the use of preventive administrative procedures for control and supervisory proceedings and is not entitled to initiate an administrative offense case. 


\section{Conclusions}

Thus, as a result of the study, the hypothesis has been proved, the essence and content of the control and supervisory proceedings have been determined; the trends of formation of the procedural model of control and supervision of production have been highlighted. To date, there has been a significant increase in the requirements for the formation of a procedural model of control and supervision activities. This circumstance is due to the reform of the system of state control and supervision announced by the Chairman of the Government of the Russian Federation in January 2019 , within the framework of which the task is not only to update the control and supervisory mechanism, but in fact to create a new model of it that meets modern socio-economic and political and legal requirements.

The prospect of the formation of the control and supervisory process is seen in the creation of an adjusted procedural model of control and supervisory production. In the structure of the administrative process, control and supervisory proceedings appear as an independent type of administrative administrative procedural activity of state control (supervision) bodies, regulated by extrajudicial administrative procedures of a preventive and restorative nature, committed in order to prevent, identify and suppress violations of mandatory requirements or requirements established by legal acts.

A promising direction of administrative and legal regulation of control and supervisory proceedings involves a focus on creating qualified forms of control and supervision in public administration, is considered as a tool to reduce excessive pressure on legal entities, which will make it possible to form a competent and consistent streamlining of procedural procedures for control and supervisory proceedings, including the application of measures administrative and legal response in an out-of-court administrative order.

In general, the analysis of the current legislation demonstrates an active process of forming a procedural model of control and supervisory proceedings. Conditions have been formed that make it possible to single out control and supervisory proceedings in the structure of the administrative process as an independent type of administrative procedural activity of executive authorities. The consolidation of the concept of control and supervisory proceedings in the law is due to the need for a correct understanding and a uniform approach of control and supervisory bodies when applying administrative and legal response measures to the determination and investigation of circumstances indicating the presence of violations of mandatory requirements or requirements established by legal acts.

\section{References:}

Davydov, P.A. 2007. The concept and characteristics of subjects of legal policy. Leningrad Legal Journal, 4. 
Khabrieva, T.Y., Marku, J. 2011. Administrative procedures and control in the light of European experience. Moscow.

Martynov, A.B. 2009. Administrative and supervisory production: concept, essence, and string of tours. Bulletin of Voronezh State University, Series "Law," 2.

Martynov, A.V. 2010. Administrative supervision in Russia: theoretical f oundations of construction. Moscow.

Nozdrachev, A.F. 2017. Reform of state control (supervision) and municipal control. Journal of Russian Law, 9.

Stakhov, A.I. 2015. On the allocation of administrative and procedural law to an independent branch of the law system of the Russian Federation. Bulletin of the University named after OE Kutafin, Moscow State University, 8.

Zyryanov, S.M. 2010. Administrative supervision. Moscow, Publishing House "Jurisprudence". 